\title{
Characterization of Arthrospira platensis cultured in wastewater of Clarias catfish farming media: DNA barcode, helical form, growth, and phycocyanin
}

\author{
MARINI WIJAYANTI ${ }^{1, \vartheta}$, M. SYAIFUDIN ${ }^{1}$, YULISMAN ${ }^{1}$, YULLY NURIANTI ${ }^{1}$, ANITA HIDAYANI ${ }^{1}$, NUNI GOFAR ${ }^{2}$ \\ ${ }^{1}$ Department of Fisheries, Faculty of Agriculture, Sriwijaya University. Jl. Palembang-Prabumulih Km 32, Indralaya, Ogan Ilir, South Sumatra, \\ Indonesia. Tel./fax.: +62-711-580059, `email: mariniwijayanti@fp.unsri.ac.id \\ ${ }^{2}$ Department of Soil Science, Faculty of Agriculture, Sriwijaya University. Jl. Palembang Prabumulih Km 32, Indralaya, Ogan Ilir, South Sumatera, \\ Indonesia
}

Manuscript received: 1 November 2020. Revision accepted: 28 November 2020.

\begin{abstract}
Wijayanti M, Syafudin M, Yulisman, Nurianti Y, Hidayani A, Gofar N. 2020. Characterization of Arthrospira platensis cultured in wastewater of Clarias catfish farming media: DNA barcode, helical form, growth, and phycocyanin. Biodiversitas 21: 58725883. Arthrospira production technology in catfish waste media can be an alternative to reduce environmental pollution. However, some environmental factors such as nutrition, light, and water content can influence characterization of Arthrospira at the genetic and physiologic level. Arthrospira platensis is one of the phycocyanin-producing cyanobacteria and can be cultured using catfish culture wastewater. Water quality especially $\mathrm{pH}$ and salinity can effect of growth rate and residue of phycocyanin from Arthrospira platensis. This study aimed to identify the species and morphological forms of Arthrospira cultured using technical fertilizer and waste media, as well as to know the phylogenetic trees between species in this study and the GeneBank based on the 16S rRNA gene, and determine the optimum of $\mathrm{pH}$ and salinity required in the medium of catfish culture wastewater to phycocyanin maximum production of Arthrospira. The optimation of $\mathrm{pH}$ and salinity method used Completely Randomized Design (CRD) factorial with 2 factors consisting of the first factor with 3 treatments and the second factor with 4 treatments and 3 replications. The first factor was $\mathrm{pH}$ of culture medium i.e. $\mathrm{pH} 6.5$ $\pm 0.2, \mathrm{pH} 8.5 \pm 0.2$ and $\mathrm{pH} 10.5 \pm 0.2$. The second factor was salinity of culture medium, that was salinity 0 ppt (parts per thousand/\%o), $10 \mathrm{ppt}, 20 \mathrm{ppt}$, and $30 \mathrm{ppt}$. Parameters observed in Arthrospira include density, growth rate, rendement of phycocyanin, and decreased total nitrogen and phosphate content in culture media. The results showed that morphology Arthrospira cultured on technical fertilizer media (AF) had a longer and helix filament compared to Arthrospira cultured on waste media (AW) which showed several linear and shorter filaments. Both samples have a genetic distance of $0.068(6.8 \%)$. Phylogenetic trees indicated that AF had a close relationship with Arthrospira platensis petH from Japan (bootstrap value 95\%). While AW formed a separate sub-cluster of AF isolates and Arthrospira platensis petH from Japan (bootstrap value of $85 \%$ ). The best treatment in this study was P2S3 (pH $8.5 \pm 0.2$ with salinity $20 \mathrm{ppt}$ ), which produced 0.867 grams maximum density, growth rate of $22.026 \%$.day ${ }^{-1}$ and $11.347 \mathrm{mg} . \mathrm{g}^{1}$ rendement of phycocyanin.
\end{abstract}

Keywords: 16S rRNA, Arthrospira, catfish culture wastewater, DNA barcode, pH, phycocyanin, phylogenetic analysis, salinity, Spirulina

\section{INTRODUCTION}

Arthrospira is a genus of cyanobacterial microalgae, commonly known under the taxonomically incorrect brand name 'Spirulina' (Papapanagiotou and Gkelis 2019). The cyanobacterial genus Arthrospira Stizenberger ex Gomont 1892 contains at present 23 species, along with 12 infraspecific taxa (Guiry and Guiry 2010). They have variety characteristics of molecular, morphology, and physiology that based on polyphasic approach. Various genotypes are adaptable to various specialized ecosystems. The combination of different methods should be based on molecular sequencing as the basic approach, to which must be added other criteria (morphological, ecological) if they are available and which are distinct and recognizable in cyanobacterial populations. A polyphasic approach to include all the criteria obtained from morphological, biochemical, molecular studies, and phylogenetic to understand cyanobacterial classification as like as Arthrospira classification (Komárek 2018).
Recent studies have shown that Arthrospira can be used for treating wastewater, including effluent from fish culture, because the biomass can metabolize the nutrients and remove the pollutant from aquaculture effluent efficiently (Zhang et al. 2019). Industrial and processing wastes and by-products for culturing Spirulina (Arthrospira) are also being considered as alternative culture media, as like as aquaculture wastewater (Wijayanti et al. 2018; Widyantoro et al. 2018; Ragaza et al. 2020). Aquaculture could apply an integrated strategy of simultaneously treating aquaculture effluent while producing the biomass to supplement fish diets. The nutrient composition in their biomass depends on their environmental factor for growing biomass. Their character could be different from the various media for growth.

Basically, Arthrospira's morphology is characterized by trichomes that circular regularly (helical). However, abnormal morphology can also occur in Arthrospira as a circular shape that is irregular even linear. In some cultivation conditions, linear filaments can spontaneously return to the helix. However, there are significant 
differences in morphology, ultrastructure, physiology, biochemistry, and genetic characteristics between the original filament and the linear filament but not the difference between the original and the returned filament. Linearization in Arthrospira is a variation on the genetic level that can be caused by several environmental factors such as nutrition, light, and content of water media for growth (Wang and Zhao 2005). According to Liu et al. (2016), DNA barcoding has developed as a reliable technology for identifying species based on variations in the sequence of standard DNA regions. This method is used successfully in a variety of biological applications including finding cryptic species, detecting invasive species, and identifying plants. DNA barcoding is a simple short genome sequence amplified via PCR using appropriate primers (Adamowicz 2015). DNA barcoding using the $16 \mathrm{~S}$ rRNA gene has been widely used to determine bacterial DNA characterization. Therefore, identification of Arthrospira using the 16S rRNA gene needs to be done to get the characterization of Arthrospira that is cultured on technical fertilizer and waste media and determine the phylogenetic tree structure that has been recorded in GeneBank.

Culture of Arthrospira (Spirulina) in Clarias pond farming wasted water could have specific characterization for optimal $\mathrm{pH}$ value and salinity. Their adaptation to grow in organic wastewater makes change in bioactive and important compound production. Their biomass has a nutritional value of $55-70 \%$ protein, 6-10\% lipid $20 \%$ carbohydrate, besides being rich in minerals, vitamins, and pigments (Borowitzka et al. 2016; Vernes et al. 2015). Some color pigments that can be produced such as phycocyanin (blue pigment), allophycocyanin (blue-green), and phycoerythrin (red pigment) (Sharma and Tiwari 2011; Vernes et al. 2015). Phycocyanin is pigment in Arthrospira which has functions as an antioxidant (Pirenantyo and Limantara 2008), a source of food coloring, cosmetics, pharmaceuticals, and drugs (Tang et al. 2020; Tiwari and Tiwari 2020), anti-inflammatory, antioxidative and anticancer (Liu et al. 2013). One of the factors that influence phycocyanin levels is biomass (Taufiqurrahmi et al. 2017). The $\mathrm{pH}$ and salinity of culture media can affect the biomass of Arthrospira (Ciferri 1983; Marek et al. 1987; Planes et al. 2002). Ismaiel et al. (2016) showed that the diversity of the chemical composition of biomass is influenced by the $\mathrm{pH}$ of the growth media. Value of $\mathrm{pH}$ and environmental factors, especially salinity, influence the productivity of cell biomass, photosynthesis, shape, and flow of cellular metabolic activity that affect the dynamics of cell composition ( $\mathrm{Hu} 2004)$. The optimal $\mathrm{pH}$ value for growth of Arthrospira sp is 7-10.5 (Hariyati 2008), and salinity from 15-30\%o (Thajuddin and Subramanian 2005). The salinity and $\mathrm{pH}$ value of Arthrospira culture media have been known to affect the morphology of the filament.

The aims of this study are characterizing morphological forms and DNA barcode based on the 16S rRNA gene of Arthrospira (Spirulina) cultured in fertilizer and waste water effluent of Clarias pond farming media, and determining optimal $\mathrm{pH}$ value and salinity of culture media for growth and phycocyanin production, especially in
Clarias pond farming waste water media and morphological changes of their filament.

\section{MATERIALS AND METHODS}

\section{Arthrospira cultured in agar media}

Bacto agar was weighed as much as $2 \mathrm{~g}$ dissolved in $100 \mathrm{~mL}$ of water. The water used was swamp water and catfish culture waste that has been filtered and sterilized using an autoclave. Sterilized swamp water was then added with 0.02 gram $\mathrm{MgSO}_{4}$ fertilizer; $\mathrm{CaCl}_{2} 0.004$ gram; EDTA 0.008 gram; urea 0.03 gram; ZA (Sulphate of Ammonia) 0.132 grams; 0.4 gram baking soda; $\mathrm{AB}$ solution $1 \mathrm{~mL}$ mix A solution (Calcium Nitrate $64.26 \%$, Potassium Nitrate $33.66 \%$, Fe EDTA $2.08 \%$ ) 2 grams / $10 \mathrm{~mL}$ and B solution (Potassium dihydro phosphate $25.83 \%$, Ammonium sulfate $9.41 \%$, Potassium sulfate $2.78 \%$, Magnesium sulfate $60.91 \%$, Cupric sulfate $0.03 \%$, Zinc sulfate $0.12 \%$, Boric acid $0.31 \%$, Manganese sulfate $0.62 \%$, Ammonium heptamolybdate $0.01 \%$ ) 2 grams $/ 10 \mathrm{~mL}$ water and TSP (Triple Super Phosphate) 0.05 grams were then homogeneous using magnetic stirrers. Next, wasted water was sterilized by an autoclave then cooled. Bactoagar was added to the technical fertilizer and waste solution to be homogenized using a magnetic stirrer and then boiled using a hot plate until all the ingredients dissolve and then autoclave again. The agar media was made with a $\mathrm{pH}$ of 7 and a salinity of $10 \mathrm{ppt}$ or 10 g.L $\mathrm{L}^{-1}$ (Hidayani et al. 2019).

Arthrospira cultivated in liquid media was taken 100 $\mu \mathrm{L}$ using micropipette and spread to the surface of a petri dish containing bactoagar media by using a sterilized spreader rod. Petri dishes were wrapped in wrapping plastic and then given a lamp lighting (light intensity 2000-4000 lux) with a dark: light ratio = 0: 24 hours. Arthrospira was observed every day until it grows blue-green. After growing, Arthrospira was re-cultured in agar media by the 4 quadrant scratch method. The cultures were used as isolate samples for determining DNA barcodes. The biomass of Arthrospira was isolated from commercial Spirulina TopSpira East Jakarta, Indonesia.

The commercial Arthrospira was cultured in technical fertilizer media directly, and we used the media based on our previous study about fertilizer media on laboratory scale (Laboratorium of Aquaculture, Faculty of Agriculture, Sriwijaya University). The result showed that this fertilizer media can substitute Zarrouk Medium (ZM) for growing Spirulina biomass in cheaper medium than ZM (Wijayanti et al. 2018).

\section{DNA extraction}

DNA extraction was carried out according to procedures in which there was a Presto TM Mini gDNA Bacteria Kit (Geneaid Biotech Ltd.). DNA extraction consisted of several stages: sample preparation, lysis, purification, and precipitation or washing. The sample used was 0.15 grams of wet weight for one extraction (Geneaid manual). 


\section{DNA amplification}

The process of DNA amplification using the PCR (Polymerase Chain Reaction) method was performed using $2 \mu \mathrm{L}$ forward primers $63 \mathrm{f}$ (5'-CAGGCC TAA CAC ATG CAA GTC-3 ') and reverse primer 1387r (5'-GGG CGG WGT GTA CAA GGC-3 ') (Marchesi et al. 1998). The total composition of the PCR mixture was $50 \mu \mathrm{L}$ which consisted of $25 \mu \mathrm{L}$ Go Taq Green, $13 \mu \mathrm{L}$ NFW (Nuclease Free Water) and $8 \mu \mathrm{L}$ Arthrospira DNA extraction template. DNA amplification was carried out in stages: the initiation cycle at $95^{\circ} \mathrm{C}$ for 5 minutes, followed by 30 denaturation cycles at $94{ }^{\circ} \mathrm{C}$ for 30 seconds, annealing at 55 ${ }^{\circ} \mathrm{C}$ for 30 seconds, then the extension stage at $72{ }^{\circ} \mathrm{C}$ for 1 minute, and the final stage $72{ }^{\circ} \mathrm{C}$ for 7 minutes (Lee et al 2003).

\section{Electrophoresis}

Electrophoresis was carried out using $1 \%$ agarose gel at $75 \mathrm{~V}$ for 35 minutes. Agarose that has been electrophoretic was immersed with a mixture of $10 \mu \mathrm{L}$ diamond dye solution and $100 \mathrm{~mL}$ TAE $1 \mathrm{x}$ buffer solution for 30 minutes without exposure to light. The results were visualized through gel documentation by observing DNA migration using a transilluminator UV.

\section{Gene sequencing}

Arthrospira DNA samples that were successfully amplified using PCR were then sequenced in the fragments of 16S rRNA gene. The amplified products were sequenced through the services of the Macrogen Institute in Jakarta. The DNA sequences obtained in the form of fasta format were aligned using MEGA 6.0 software and then uploaded through the Basic Local Alignment Search Tool (BLAST) program. BLAST was a program to search for and analyze the homology of an organism's sequence, on the ncbi.nlm.nih.gov website so that its homology can be identified with another genus Arthrospira 16S rRNA gene sequences registered in the GenBank database. The genetic distance and phylogenetic trees between genera were constructed using the Neighbor-Joining (NJ) method. The phylogenetic tree was constructed through the Mega 6.0 software application using the Neighbor-Joining (NJ) method of the Maximum Composite Likelihood model and Substitutions to include d: Transitions + Transversions with 1000x bootstrap. Meanwhile, Arthrospira morphological form analysis was presented in the form of images and discussed descriptively by referring to the appropriate literature.

\section{Optimization of pH and salinity for growing Arthrospira in Catfish farming wasted water}

The experimental design for optimizing $\mathrm{pH}$ and salinity media for growing Arthrospira in Catfish farming wasted water was a Factorial Completely Randomized Design (CRD) consisting of the first factor with 3 treatments and the second factor with 4 treatments and 3 replications. The first factor was the difference of $\mathrm{pH}$ in culture media, including P1: culture media pH $6.5 \pm 0.2, \mathrm{P} 2$ : culture media $\mathrm{pH} 8.5 \pm 0.2$, and P3: culture media $\mathrm{pH} 10.5 \pm 0.2$. The second factor was the difference of salinity in culture media i.e. S1: salinity of $0 \%$, S2: salinity of $10 \%$, S3: salinity of $20 \%$, and S4: salinity of $30 \%$.

\section{Culture preparation}

The equipment used in this study was sterilized using $70 \%$ alcohol to minimize the contaminants that inhibit the productivity of Arthrospira. The containers used plastic bottles with capacity of $5 \mathrm{~L}$ volume of 36 units. The plastic bottle was sterilized using a potassium permanganate solution $\left(2 \mathrm{mg} . \mathrm{L}^{-1}\right)$. Catfish culture wastewater obtained from catfish farming ponds measuring $2 \mathrm{~m} \times 1 \mathrm{~m} \times 1 \mathrm{~m}$, and high water media was $20 \mathrm{~cm}$ (Figure 1). The density used in the pond was 330 fish. $400 \mathrm{~L}^{-1}$ with 150 grams fish $^{-}$ ${ }^{1}$, maintained for 2 months by providing artificial feed (protein 31\%-33\%), twice per day at satiation. Catfish culture wastewater was previously sterilized by boiling in an autoclave and then cooled, while the steril wastewater was treated with salinity. In treatments S1, S2, S3, and S4 were added with salt until salinity was obtained according to the treatment. The wastewater media had a $\mathrm{pH}$ of 7.3, therefore there was an addition of $\mathrm{HCl} 1 \mathrm{~N}$ of $0.75 \mathrm{~mL} \mathrm{~L}^{-1}$ in $\mathrm{P} 1$ treatment to reach a $\mathrm{pH}$ of 6.5 . Meanwhile,. in treatments $\mathrm{P} 2$ and $\mathrm{P} 3$, to get a $\mathrm{pH}$ of 8.5 and $\mathrm{pH} 10.5$ there was an addition of $\mathrm{NaOH} 8 \mathrm{~N}$ as much as $0.07 \mathrm{~mL} \mathrm{~L}^{-1}$ and $0.45 \mathrm{~mL} \mathrm{~L}^{-1}$.

\section{Arthrospira cultivation}

Arthrospira previously used was cultured in catfish culture wastewater for culture stock with a density of $2 \mathrm{~g} \mathrm{~L}^{-}$

${ }^{1}$. The stock was taken as much as $400 \mathrm{~mL}$ in $3600 \mathrm{~mL}$ of catfish culture wastewater in accordance with treatment. Aeration was used for agitation, the lighting using 36 watt TL lamps for 24 hours day ${ }^{-1}$ during maintenance (Figure 2). Harvest of biomass. The components of wastewater were total phosphorus $2,6 \mathrm{mg} . \mathrm{L}^{-1}$, total nitrogen $1,9 \mathrm{mg} . \mathrm{L}^{-1}$, total organic carbon $11.4 \mathrm{mg} . \mathrm{L}^{-1}$. Harvest of the biomass was after exponential phase by filtering. The biomass was dried using an oven for 14 hours at $40^{\circ} \mathrm{C}$ (Hidayani et al. 2019). The dry biomass was used for the phycocyanin extraction process.

\section{Phycocyanin extraction}

The dry biomass was $0.04 \mathrm{~g}$ added by $1 \mathrm{~mL}$ of phosphate buffer $\mathrm{pH} 7$, then homogenized and frozen in the freezer for 24 hours at a temperature of $-4{ }^{\circ} \mathrm{C}$. After 24 hours from the freezer, thawing process for 15 minutes. Samples were centrifuged for 30 minutes at $3000 \mathrm{rpm}$. After that, the sediment and the supernatant were separated. The resulting supernatant was phycocyanin which be analyzed using the Bennett and Bogorad method (1973).

\section{The density of Arthrospira biomass}

Biomass density measurements were performed at each treatment and 3 replications every day at the same hour. The density of biomass was $1 \mathrm{~mL}$ of sample in each treatment with 3 replications. The $1 \mathrm{~mL}$ of sample into aluminum bowl. The sample and the aluminum bowl were weighed, then dried in the oven for 14 hours at $40{ }^{\circ} \mathrm{C}$. The sample of water that had dried was weighed again. The dry biomass weight of Arthrospira biomass was converted to $\mathrm{g} \mathrm{L}^{-1}$. 


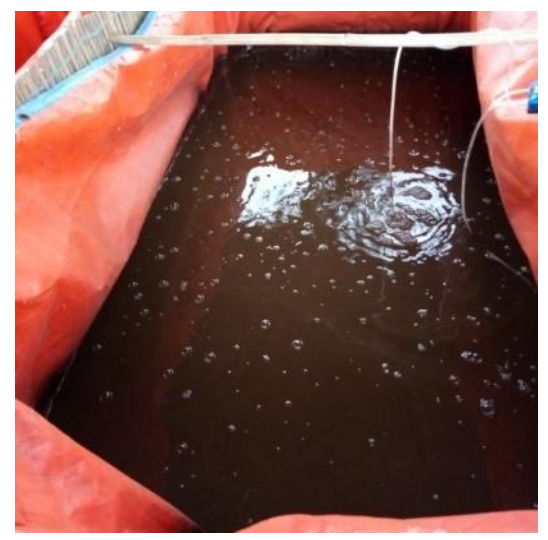

Figure 1. Catfish farming pond

The growth rate of Arthrospira can be calculated using the following formula according to Vonshak (1997):

$$
\mu=\frac{\ln \mathrm{Nt}-\ln \mathrm{No}}{\mathrm{t}} \times 100 \%
$$

Where:

$\mu=$ daily growth rate $\left(\%\right.$ days $\left.^{-1}\right)$

$\mathrm{t}=$ time (days) from $\mathrm{N}_{0}$ to $\mathrm{N}_{\mathrm{t}}$

$\mathrm{N}_{0}=$ initial density $\left(\mathrm{g} \mathrm{L}^{-1}\right)$

$\mathrm{N}_{\mathrm{t}}=$ density at the time $\mathrm{t}\left(\mathrm{g} \mathrm{L}^{-1}\right)$

Measurement of total nitrogen and phosphate content in culture media was carried out at the beginning and the first day after the peak phase of each treatment.

The measurement of phycocyanin refers to Bennett and Bogorad (1973). The absorbed supernatant was measured using a spectrophotometer at wavelengths of $615 \mathrm{~nm}$ and $652 \mathrm{~nm}$.

$$
\text { C-phycocyanin }\left(\mathrm{mg} \cdot \mathrm{mL}^{-1}\right)=\frac{(\mathrm{OD} 615)-0.474(\mathrm{OD} 652)}{5.34}
$$

Rendement of phycocyanin $\left(\mathrm{mg} \mathrm{g}^{-1}\right)=$ C-phycocyanin $\mathrm{x} \mathrm{V}$

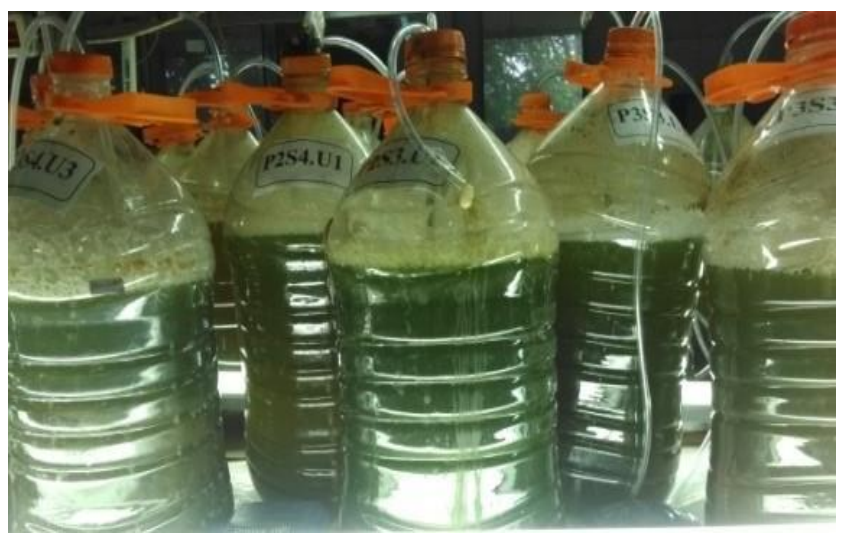

Figure 2. Arthrospira cultivation

Rendement percentage of phycocyanin $(\%)=$ Rendement of phycocyanin $\left(\mathrm{mg} \mathrm{g}^{-1}\right) \times 100 \%$

Where:

C-phycocyanin $=\mathrm{C}$-phycocyanin consentration $\left(\mathrm{mg} \cdot \mathrm{mL}^{-1}\right)$ $\mathrm{V}=$ Solvent Volume $(\mathrm{mL})$

$\mathrm{DB}=$ Dry Biomass $(0.04 \mathrm{~g})$

0.474 and $5.34=$ coefficient of extinction (Bennett and Bogorad 1973)

The results were submitted to simple analysis of variance tests (ANOVA) $(\mathrm{p}<0.05)$ and in the case of significant differences, the means were compared by the Least Significant Differences test $(\mathrm{p}<0.05)$.

\section{RESULTS AND DISCUSSION}

\section{Morphology of Arthrospira}

Arthrospira was cultivated using two different fertilizer media namely technical fertilizer and waste media. The morphology of commercial Arthrospira before fertilizer treatment was presented in Figure 3.

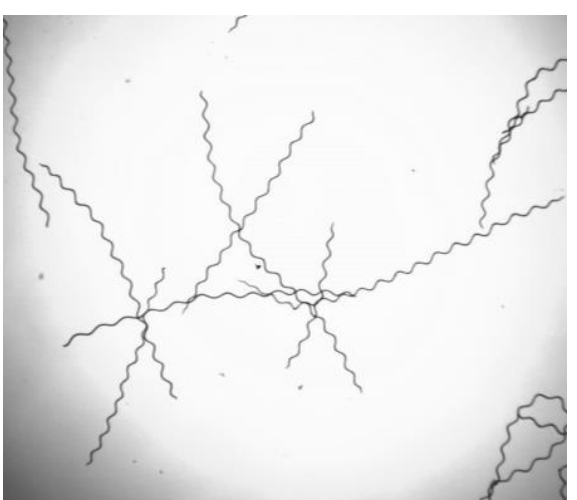

CA

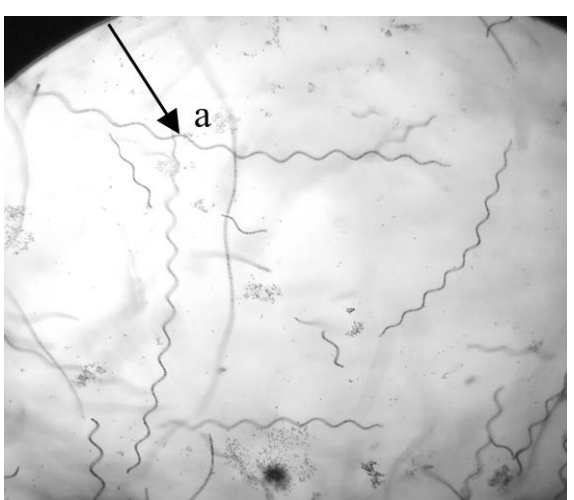

AF

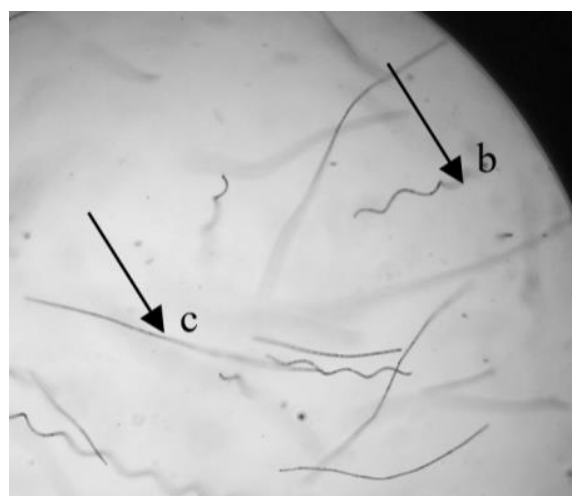

AW

Figure 3. Morphological identification results of Arthrospira isolate. (CA =Commercial Arthrospira; $\mathrm{AF}=\mathrm{commercial}$ Arthrospira cultured with technical fertilizer media; AW= commercial Arthrospira cultured with waste media) 40x magnification. Note: a = helical form $\mathrm{AF}, \mathrm{b}=$ helical form $\mathrm{AW}, \mathrm{c}=$ straight form $\mathrm{AW}$ 
Tabel. 1. The results of the BLASTn analysis of Arthrospira samples cultivated in technical fertilizer and waste medium with data in GenBank

\begin{tabular}{|c|c|c|c|}
\hline Description & Identity (\%) & Access code & Sample origin \\
\hline \multicolumn{4}{|l|}{ Arthrospira (fertilizer media) (AF) } \\
\hline Arthrospira platensis petH & 100 & AB113346 & Japan \\
\hline Spirulina platensis CCC 478 & 90,48 & JX014313.1 & India \\
\hline Spirulina platensis cyaG & 94,4 & D49531.1 & Japan \\
\hline Arthrospira platensis PCC 7345 & 90,12 & JN831264.1 & USA \\
\hline Arthrospira maxima EEW2 & 74,4 & HQ008225 & Australia \\
\hline \multicolumn{4}{|l|}{ Arthrospira (waste media) (AW) } \\
\hline Arthrospira platensis petH & 94,3 & D49531.1 & Japan \\
\hline Arthrospira platensis DKCAS2 & 81,4 & MG912588.1 & India \\
\hline Spirulina platensis CCC 478 & 74,4 & JX014313.1 & India \\
\hline Arthrospira maxima str. Lefevre 1963/M-132-1 & 73,3 & FJ798612 & Venezuella \\
\hline Arthrospira maxima EEW2 & 72,2 & HQ008225 & Australia \\
\hline
\end{tabular}

The results of the identification of isolates showed that the isolate had a twisted filament shape resembling a spiral (helical). Based on Davis's identification book (1955), it is known that the isolate used in the study was Spirulina (Arthrospira) platensis. Arthrospira is cyanobacteria belonging to the order Oscillatoriales which has a filament (trichome) that resembles a spiral (helical) but does not have heterocyst cells (Sze 1998). Heterocyst cells are special thick-walled cells that play a role in nitrogen fixation from the air (Issa et al. 2014). In this study, Arthrospira cultured in different media had several linear/straight morphologies.

Based on Figure 2, Arthrospira which was cultured on technical fertilizer media has a longer and spiraling morphological form compared to another cultured on waste media. Their filaments have more linear morphological form, some spirals but not too long. According to Astiani et al. (2016), Arthrospira growth is influenced by nutritional and environmental factors. Wang and Zhao (2005) explained that linearization that occurs in Arthrospira is a variation on the genetic level that can be caused by environmental factors such as lack of nutrition and high light intensity. In this study, isolates were cultured with the same light intensity of 2000-3000 lux with a light-dark ratio of 0: 24 hours. Linear filaments in AW have a lower metabolic rate compared to helical filaments. This is one of the adaptive mechanisms for Arthrospira to survive some environmental conditions that are not appropriate.

Yadav et al. (2020) showed that helical and linear morphotypes of Arthrospira sp. display genomic differences. Vonshak (2000) showed that polyphasic in Arthrospira morphotypes can be caused by: growing in agar/solid media, light stress-photoinhibition, irradiation, and temperature, effect of physical and chemical conditions. Arthrospira is prokaryotic organism, so it is easy to mutate and change sequences in their genome.

\section{Phylogenetic tree}

The results of the $16 \mathrm{~S}$ rRNA encoding gene sequences from AF and AW isolates were traced to other Arthrospira isolates present in GenBank through the BLAST program.
The results of the BLASTn analysis of Arthrospira samples cultivated in technical fertilizer and waste media with data in GenBank are presented in Table 1. Table 1 results of the BLAST analysis show the closeness between AF and AW isolates with other isolates in GenBank. It shows that Arthrospira technical fertilizer isolates and Arthrospira waste isolates have the closest homology to Arthrospira platensis petH species from Japan with percentage values respectively $100 \%$ and $94.3 \%$.

Genetic distance was used to see kinship relationships from Arthrospira both AF and AW samples with sequential data from GenBank. AF isolates indicated a genetic distance of 0.068 with $\mathrm{AW}$ isolates. AW and AF isolates showed the lowest genetic distance respectively 0.089 and 0.060 with Arthrospira platensis petH from Japan. Analysis based on genetic distance showed that both isolates belonged to the same species namely Spirulina platensis, however, the genetic distance was $0.068(6.8 \%)$ meaning that there are intraspecies variations in the sample caused by mutations.

Phylogenetic tree Arthrospira isolates from technical fertilizer and waste media were presented in Figure 4. The phylogenetic tree is a two-dimensional graph showing relationships between organisms or population classifications based on their evolutionary history. The result of phylogenetic tree construction showed that both samples formed branches with a cluster. Phylogenetic tree from $\mathrm{AF}$ and $\mathrm{AW}$ isolate sequences formed cluster was separate with several other Arthrospira species from GenBank data.

The AF isolates had a close relationship with Arthrospira platensis petH species from Japan with a bootstrap value of $95 \%$. Hadiati (2003) states that bootstrap analysis is performed to determine the level of confidence in grouping. Bootstrap value is considered high because according to Hall (2001), a clade can be trusted with a bootstrap value of $90 \%$. In addition, Hillis and Bull (1993) state that bootstrap analysis with values of $70 \%$ or higher indicates a reliable grouping. The AW isolates formed a separate branch of AF isolates and Arthrospira platensis petH species. Genetically, they had diverse, and adapted to 
environmental conditions. The AW isolate indicated different strains from AF isolate groups. Ballot et al. (2004) stated that Spirulina from the same species and cultured under different conditions can form a separate subcluster with a bootstrap value of $79 \%$. Zhao et al. (2006) identified and analyzed the number of restriction-modification genes in the cyanobacterial genome, seeing that more restrictionmodification genes were found in cyanobacterial filaments (Anabaena, Spirulina, and Nostoc) than dispenses (Synechocystis, Synechococcus and Prochlorococcus) this was due to the organism adapting to various environmental conditions, or the many variations in sources of nutrients that cause mutations.

\section{Density and Growth Rate of Arthrospira cultured in wastewater of catfish farming}

The biomass of Arthrospira displayed mechanism of adaptation in culture media. The wastewater media could make different characteristic of growth as like as filament. The maximum densities of Arthrospira cultured in wasted water were achieved on a different day. The daily density of Arthrospira during culture can be seen in Figure 5.
The graph presented in Figure 5, it shows that in the culture period from day 1 to day 2, Arthrospira in each treatment-experienced slow growth, because the cells were still adapting to their new environment. The exponential phase for the treatment of P2S2, P2S3, and P3S3 lasts from day 1 to day 8 of the culture period. The treatment of P2S1, $\mathrm{P} 2 \mathrm{~S} 4, \mathrm{P} 3 \mathrm{~S} 1$ and P3S2 takes place from $2^{\text {nd }}$ until $8^{\text {th }}$ day of the culture period. While the treatment of P1S1, P1S2, P1S3, P1S4, and P3S4 lasted from $3^{\text {rd }}-8^{\text {th }}$ day of the culture period. The decreasing Arthrospira density for the treatment occurred from day 9 to day 11 of the culture. Lesmana et al. (2019) explained that the adaptation phase lasts from day 0 to day 1 , while the exponential phase occurs from day 1 to day 7, and experiences a stationary phase from day 7 to day 9 then enters the death phase after the $7^{\text {th }}$ day and $9^{\text {th }}$ day. The decrease of density could because of reducing the nutrients in the culture media. Soni et al. (2019), the concentration of nutrients in the media decreased after reaching the peak period. This is due to the higher density of Arthrospira in the culture media.
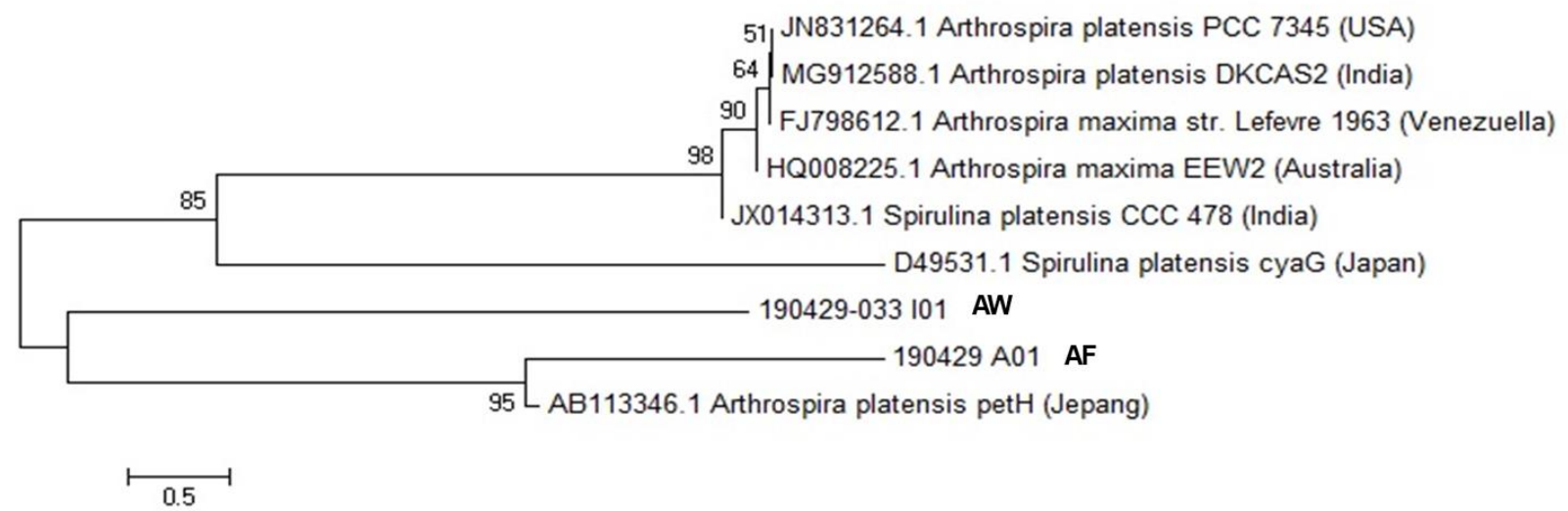

Figure 4. Phylogenetic analysis with 1000 bootstrap AW (Arthrospira cultured in wastewater media) and AF (Arthrospira cultured in fertilizer media)

Biomass density $\left(\mathrm{g} . \mathrm{L}^{-1}\right)$
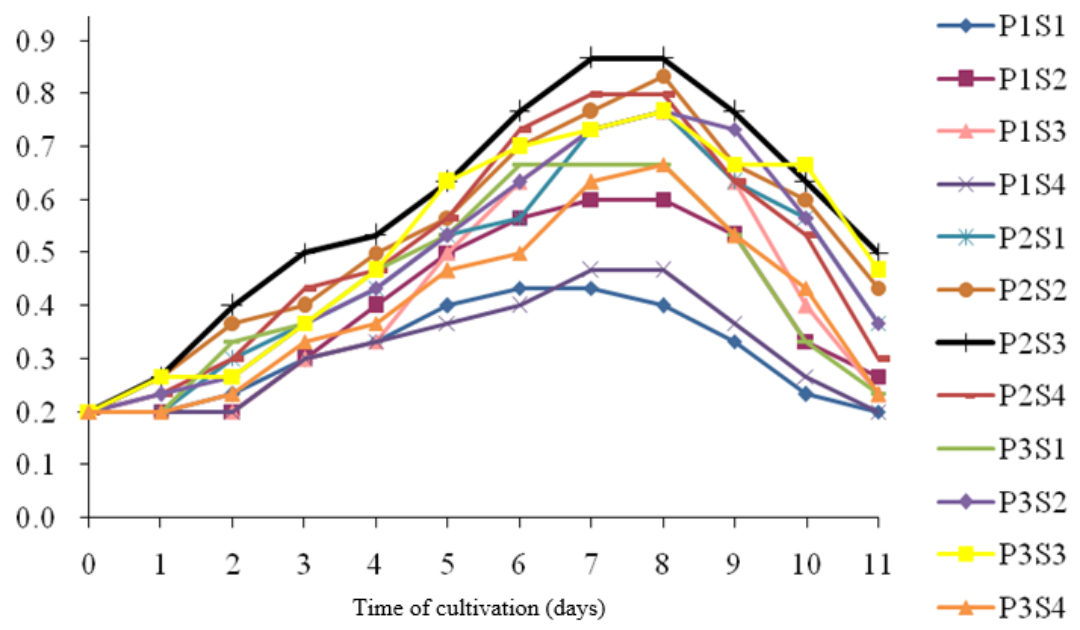

Note:

P1: culture media pH $6.5 \pm 0.2$,

P2: culture media pH $8.5 \pm 0.2$

P3: culture media $\mathrm{pH} 10.5 \pm 0.2$.

S1: salinity of $0 \%$,

S2: salinity of $10 \%$,

S3: salinity of $20 \%$,

S4: salinity of $30 \%$ 
Figure 5. Cell density (dry weight with a moisture content of 1.2\%) of Arthrospira in catfish rearing pond wastewater

The maximum density of Arthrospira could be achieved on different days, between 5 - 8 days after culturing. The mean of maximum density could be $0.433-0.867 \mathrm{~g} \mathrm{~L}^{-1}$ of dry biomass cultured in catfish rearing wastewater. The maximum cell density of $A$. platensis which cultured in nile fish rearing wastewater, resulted in the production of $0.22 \mathrm{~g}$ $\mathrm{L}^{-1}$ of dry biomass and maximum productivity of $0.03 \mathrm{~g} \mathrm{~L}^{-1}$ day $^{-1}$ (Nogueira et al. 2018). The catfish rearing pond wastewater has high potential as cultivation media for Arthrospira production.

The analysis of variance showed that differences in $\mathrm{pH}$, salinity, and interaction between factors ( $\mathrm{pH}$ and salinity) significantly affect the maximum density and growth rate of Arthrospira platensis. The results of the LSD 0.05 maximum density test and growth rate sequentially were presented in Tables 1 and 2 . LSD $_{0.05}$ test results on the main factors of differences in $\mathrm{pH}$, density, and growth rate of Arthrospira platensis in the $\mathrm{P} 2$ treatment ( $\mathrm{pH} 8.5 \pm 0.2$ ) were significantly higher than those in the $\mathrm{P} 1(\mathrm{pH} 6.5 \pm$ 0.2 ) and $\mathrm{P} 3$ treatments $(\mathrm{pH} 10.5 \pm 0.2)$. According to Ismaiel (2016), the highest biomass of Arthrospira platensis is produced in media with a $\mathrm{pH}$ of 8.5-9.5. Although Arthrospira platensis can tolerate a wide $\mathrm{pH}$ range, a $\mathrm{pH}$ range farther from its optimal $\mathrm{pH}$ can reduce its growth rate. A low growth rate will also cause low biomass production.

Furthermore, the different salinity treatment factors showed that the maximum density and growth rate in treatment S3 (salinity of $20 \%$ ) were significantly higher compared to S1 (salinity of $0 \%$ ), S2 (salinity of $10 \%$ ) and S4 (salinity of $30 \%$ ) treatments. The S1 and S4 treatments were not significantly different and were the treatments that produced the lowest density compared to other treatments.
Tables 1 and 2 showed that the highest density and daily growth rate was found in the S3 (salinity of $20 \%$ ) treatment. This is supported by the results of Kouhgardi et al. (2015), that Arthrospira platensis cultured on Conway media was able to produce the highest density of 912.07 $\mathrm{mL}^{-1}$ cells at a salinity of $20 \%$. While the density and growth rate between $\mathrm{S} 1$ and $\mathrm{S} 4$ treatments showed no significant difference. This is because the salinity of 0-30 $\%$ is still within the range of salinity that can be tolerated by Arthrospira. Ughy et al. (2015) said that Arthrospira platensis is one of the species of Cyanobacteria that can grow in an euryhaline environment.

The interaction between $\mathrm{pH}$ and salinity factors showed that the density and growth rate in treatment $\mathrm{P} 2 \mathrm{~S} 3(\mathrm{pH} 8.5$ \pm 0.2 and salinity of $20 \%$ ) were significantly higher compared to other treatments. At maximum density, treatment P2S3 was not significantly different from treatments such as P1S3, P2S1, P2S2, P2S4, and P3S3. While in the growth rate, treatment $\mathrm{P} 2 \mathrm{~S} 3$ was not significantly different from P1S3, P2S2, P2S4, P3S2 and treatments P3S3. Tables 1 and 2 show that treatment P2 ( $\mathrm{pH} 8.5 \pm 0.2)$ is more dominant causing higher density and growth rate of Arthrospira platensis despite being in different salinity ranges. As for the treatments $\mathrm{P} 1(\mathrm{pH} 6.5 \pm$ $0.2)$ and $\mathrm{P} 3(\mathrm{pH} 10.5 \pm 0.2)$ provide the highest density when combined by the treatment S3 (salinity $20 \mathrm{ppt}$ ). The treatment of $\mathrm{P} 1, \mathrm{P} 2$, and $\mathrm{P} 3(\mathrm{pH} 6.5 \pm 0.2,8.5 \pm 0.2$, and $10,5 \pm 0.2$ ) and $\mathrm{S} 1, \mathrm{~S} 2, \mathrm{~S} 3$ and $\mathrm{S} 4$ treatments (salinity of 0 $\%$, $10 \%$, $20 \%$, and $30 \%$ ) still support the growth of Arthrospira platensis with the best treatment found in the combined treatment $\mathrm{P} 2 \mathrm{~S} 3$ ( $\mathrm{pH} 8.5 \pm 0.2$ with salinity of 20 $\%$ ).

Table 1. Maximum density of Arthrospira platensis $\left(\mathrm{g} \mathrm{L}^{-1}\right)$

\begin{tabular}{|c|c|c|c|c|c|}
\hline \multirow{2}{*}{$\begin{array}{c}\text { Single INFLUENCE of } \\
\text { pH (P) }\end{array}$} & \multicolumn{4}{|c|}{$\begin{array}{l}\text { Single influence of salinity (S) } \\
\left(\mathrm{LSD}_{0,05}=0.107\right)\end{array}$} & \multirow{2}{*}{$\begin{array}{l}\text { Main influence of pH }(P) \\
\quad\left(\text { LSD }_{0,05}=\mathbf{0 . 0 5 3}\right)\end{array}$} \\
\hline & S1 (0 \%o) & S2 (10 \%o) & S3 (20 \%) & S4 (30 \%o) & \\
\hline $\mathrm{P} 1$ (pH 6.5) & $0.433^{\mathrm{a}}$ & $0.633^{b}$ & $0.767^{\text {cdef }}$ & $0.467^{\mathrm{a}}$ & $0.575^{\mathrm{a}}$ \\
\hline $\mathrm{P} 2(\mathrm{pH} 8.5)$ & $0.767^{\text {cdef }}$ & 0.833 ef & $0.867^{\mathrm{f}}$ & $0.800^{\text {def }}$ & $0.817^{\mathrm{c}}$ \\
\hline P3 (pH 10.5) & $0.667^{\mathrm{bc}}$ & $0.733^{\text {bcde }}$ & $0.767^{\text {cdef }}$ & $0.700^{\mathrm{bcd}}$ & $0.717^{\mathrm{b}}$ \\
\hline $\begin{array}{l}\text { Main influence of salinity } \\
\text { (S) }\left(\mathrm{LSD}_{0,05}=0.062\right)\end{array}$ & $0.622^{\mathrm{a}}$ & $0.733^{b}$ & $0.800^{\mathrm{c}}$ & $0.656^{\mathrm{a}}$ & \\
\hline
\end{tabular}

Table 2. The growth rate of Arthrospira platensis cultured in $\mathrm{pH}$ and salinity treatment $\left(\%\right.$ day $\left.^{-1}\right)$

\begin{tabular}{|c|c|c|c|c|c|}
\hline \multirow[t]{2}{*}{ Single influence of pH (P) } & \multicolumn{4}{|c|}{$\begin{array}{l}\text { Single influence of salinity }(\mathrm{S}) \\
\left(\mathrm{LSD}_{0,05}=\mathbf{3 . 2 2 4}\right)\end{array}$} & \multirow{2}{*}{$\begin{array}{l}\text { Main influence of pH }(\mathrm{P}) \\
\left(\mathrm{LSD}_{0,05}=1.612\right)\end{array}$} \\
\hline & S1 (0 \%o) & S2 (10 \%) & S3 (20 \%o) & S4 (30 \%) & \\
\hline $\mathrm{P} 1(\mathrm{pH} 6.5)$ & $14.333^{\mathrm{a}}$ & $18.659^{\mathrm{cd}}$ & $19.192^{\text {cde }}$ & $13.348^{\mathrm{a}}$ & $16.383^{\mathrm{a}}$ \\
\hline $\mathrm{P} 2(\mathrm{pH} 8.5)$ & $18.343^{\mathrm{bcd}}$ & $20.570^{\text {de }}$ & $22.026^{\mathrm{e}}$ & $20.723^{\mathrm{de}}$ & $20.416^{b}$ \\
\hline $\mathrm{P} 3(\mathrm{pH} 10.5)$ & 20.023 de & $19.527^{\text {cde }}$ & $20.623^{\mathrm{de}}$ & 16.417 abc & $19.147^{b}$ \\
\hline $\begin{array}{l}\text { Main influence of salinity } \\
\text { (S) }\left(\operatorname{LSD}_{0,05}=1.861\right)\end{array}$ & $17.566^{\mathrm{a}}$ & $19.585^{b}$ & $20.614^{b}$ & $16.829^{\mathrm{a}}$ & \\
\hline
\end{tabular}

Note: $\%$ means part per thousand (ppt), it is not percent $(\%)$. Salinity of freshwater $(0 \mathrm{ppt})$, brackish water $(5-20 \mathrm{ppt})$, and sea water (more than $25 \mathrm{ppt}$ ). The salinity used in this study still supports the growth of Arthrospira (Vonshak 1997). 
Mismatch of $\mathrm{pH}$ will cause lysis and can change the shape of pigment growth (Hariyati 2008). The process of photosynthesis affects $\mathrm{pH}$ value. In daylight, aquatic plants release carbon dioxide from water for use in photosynthesis. The release of carbon dioxide by plants occurs through respiration. When carbon dioxide is released, carbonate builds up and hydrolyzed so that the $\mathrm{pH}$ of the water will increase (Boyd 1990). Prasadi (2018) showed that growth of Arthrospira could be inhibited if it was in the $\mathrm{pH}$ range above 10.5 or less than 7 . Salinity is one of the factors that can influence osmotic pressure for Arthrospira as like others of microalgae. Pisal and Lele (2005) microalgae can experience cell shrinkage in conditions outside the cell salinity higher than inside the cell (hypertonic), and vice versa under conditions of low salinity outside the cell (hypotonic) cell swelling will occur due to water molecules outside moves into the cell. This condition affects the process of photosynthesis, and makes microalgae to produce secondary metabolites in the form of $\beta$-carotene to sustain life against changes in salinity in culture media. While in isotonic conditions, cell fluid is isotonic to its external media which causes low active ion transport and osmoefector exchange, making the Na-KATPase enzyme activity at a maximum level and more energy will be utilized for growth (Rahmawati et al. 2012). The optimal combination of $\mathrm{pH}$ and salinity causes the growth of Arthrospira to be maximal. The optimal salinity range for Arthrospira is between 15-20\%, from the related research showed that the results of Arthrospira culture with $20 \%$ of media salinity, $\mathrm{pH}$ 7.5-8.5 using fertilizer media (0.010 $\mathrm{g} \mathrm{L}^{-1} \mathrm{TSP}, 0.030 \mathrm{~g} \mathrm{~L}^{-1}$ Urea, and $0.030 \mathrm{~g} \mathrm{~L}^{-1} \mathrm{ZA}$ ) and a culture period of 9 days produced a dry weight of Arthrospira of $0.0375 \mathrm{~g} \mathrm{~L}^{-1}$ (Prasadi 2018).

\section{Rendement of phycocyanin}

The rendement of Arthrospira was presented in Table 3. The $\mathrm{pH}$ condition of maintenance media can be affect protein content in Arthrospira cells. The results of LSD 0.05 on the main factor of $\mathrm{pH}$ showed that the rendement of phycocyanin Arthrospira in treatment P2 was significantly higher compared to other treatments. Taufiqurrahmi et al. (2017), the amount of Arthrospira biomass influences the high content of phycocyanin. Table1 showed that the highest of Arthrospira biomass was found in treatment P2. It showed that the highest Arthrospira biomass produced the highest rendement of phycocyanin (Table 3). The culture medium of Arthrospira $\mathrm{pH}$ of 8.5 produced the highest C-phycocyanin content (Ismaiel et al. 2016). Rahmawati et al. (2017) said that the higher C-phycocyanin followed the higher of rendement of phycocyanin.

LSD 0.05 showed that the main factor of salinity showed the rendement of phycocyanin in treatment S3 (salinity of $20 \%$ ) was significantly higher than other treatments. It is thought that the difference in salinity treatment has an impact on the external osmotic pressure of Arthrospira cells which results in changes in cell composition especially phycocyanin. Sodium will flow into the cell and cause the release of phycobilin (phycoerythrin, phycocyanin and allophycocyanin) from PS II (Photosystem II) and stop the electrons transporting to PS I (Photosystem I) followed by activation of the protective mechanism. Arthrospira will produce carbohydrates to balance intracellular osmotic pressure and require more energy to remove sodium ions from cells. In this case it will produce ammonium assimilation causes inhibition of protein synthesis (Zhou et al. 2017).

The environment includes the availability of nutrients, $\mathrm{pH}$, salinity, light and temperature can affect the growth and accumulation of biopigments from microalgae (Sharma and Tiwari 2014). The condition of culture media is able to influence the growth phase of Arthrospira, causing changes in the composition and proportion of phycobilin (phycoerythrin, phycocyanin and allophycocyanin) (Simeunovic et al. 2013). The results of the LSD 0.05 was showed that the rendement of phycocyanin Arthrospira on the interaction between factors in treatment P2S3 was significantly higher than in other treatments, but it was not significantly different from treatment P2S2. This showed the density and growth rate of Arthrospira. The increasing salinity will cause maintenance media to be hypertonic towards cells and result in poor absorption of nutrients by cells. These cells could reduce protein and increase in carbohydrates from Arthrospira cells (Ravelonandro et al.,2011).

Production of phycocyanin was able to reach $12.4 \%$ $17.6 \%$ of biomass dry weight of Arthrospira cultured in Zarrouk Medium (ZM) (Prates et al. 2018; Garcia-Lopez et al. 2020). There are several factors that affect the rendement of phycocyanin include temperature, extraction time, mixing rate, biomass, type of solvent, and the ratio of biomass to the solvent (Taufiqurrahmi et al. 2016). The content of phycocyanin in cyanobacteria increases when grown in low light intensity. Phycocyanin is a pigment associated with protein, polar and water-soluble. The protein content of microalgae is influenced by environmental conditions such as temperature, age of culture, light intensity, $\mathrm{pH}$, salinity, and nutrient limits (especially nitrogen). Nitrogen is an essential element needed for the synthesis of accessory pigments and chlorophyll. When microalgae are growing fast, it requires large amounts of nitrogen and could consume phycocyanin as an alternative source of nitrogen for the production of biomass (Hsieh-Lo et al. 2019). It must be optimized for biomass production and phycocyanin content. The higher concentration of phycocyanin will be followed by the rendement of phycocyanin. In this study, the phycocyanin content is lower than previous study, because of different media for culturing Arthrospira. The nutrient from ZM (pro analysis substances) is more complete for growing and forming phycocyanin than wastewater catfish pond media, especially the trace mineral in ZM.

\section{Reduction of total nitrogen and phosphate content}

The percentage reduction of total nitrogen in the culture media was presented in Table 4. 
Table 3. Phycocyanin (\%) yield in Arthrospira dry biomass at 8 days after inoculation

\begin{tabular}{|c|c|c|c|c|c|}
\hline \multirow[t]{2}{*}{ Single Influence of $\mathbf{p H}(\mathrm{P})$} & \multicolumn{4}{|c|}{$\begin{array}{l}\text { Single influence of salinity }(S) \\
\left(\mathrm{LSD}_{0,05}=0.194\right)\end{array}$} & \multirow{2}{*}{$\begin{array}{l}\text { Main influence of pH }(P) \\
\quad\left(\text { LSD }_{0,05}=0.096\right)\end{array}$} \\
\hline & S1 & S2 & S3 & S4 & \\
\hline P1 & $7.881^{\mathrm{a}}$ & $8.783^{c}$ & $9.441^{\mathrm{d}}$ & $8.387^{\mathrm{b}}$ & $8.623^{a}$ \\
\hline $\mathrm{P} 2$ & $9.657^{\mathrm{e}}$ & $10.906^{\mathrm{h}}$ & $11.347^{\mathrm{i}}$ & $10.423^{\mathrm{g}}$ & $10.583^{c}$ \\
\hline $\mathrm{P} 3$ & $8.970^{\mathrm{c}}$ & $9.408^{d}$ & $10.134^{\mathrm{f}}$ & $9.262^{\mathrm{d}}$ & $9.444^{b}$ \\
\hline $\begin{array}{l}\text { Main influence of salinity } \\
\text { (S) }\left(\operatorname{LSD}_{0,05}=0.111\right)\end{array}$ & $8.836^{\mathrm{a}}$ & $9.699^{c}$ & $10.307^{\mathrm{d}}$ & $9.357^{\mathrm{b}}$ & \\
\hline
\end{tabular}

Table 4. Reduction of total nitrogen content in Arthrospira culture medium (\%)

\begin{tabular}{|c|c|c|c|c|c|}
\hline \multirow[t]{2}{*}{ Single Influence of $\mathrm{pH}(\mathrm{P})$} & \multicolumn{4}{|c|}{$\begin{array}{c}\text { Single influence of salinity (S) } \\
\left(\mathrm{LSD}_{0,05}=\mathbf{1 . 2 9 0}\right)\end{array}$} & \multirow{2}{*}{$\begin{array}{c}\text { Main influence of } \mathbf{p H} \\
(\mathbf{P}) \\
\text { (LSD }_{\mathbf{0}, 05}=\mathbf{0 . 6 4 5 )}\end{array}$} \\
\hline & S1 & S2 & S3 & S4 & \\
\hline P1 & $80.990^{\mathrm{a}}$ & $82.250^{\mathrm{ab}}$ & $83.767^{\text {cde }}$ & $81.897^{\mathrm{ab}}$ & $82.226^{\mathrm{a}}$ \\
\hline $\mathrm{P} 2$ & 83.880 de & 84.377 ef & $85.420^{\mathrm{f}}$ & 84.857 ef & $84.633^{c}$ \\
\hline $\mathrm{P} 3$ & $82.940^{\mathrm{bcd}}$ & $81.143^{\mathrm{a}}$ & 84.950 ef & 84.813 ef & $83.462^{b}$ \\
\hline $\begin{array}{l}\text { Main influence of Salinity } \\
\text { (S) }\left(\operatorname{LSD}_{0,05}=0.745\right)\end{array}$ & $82.590^{a}$ & $83.856^{\mathrm{b}}$ & $84.712^{c}$ & $82.603^{\mathrm{a}}$ & \\
\hline
\end{tabular}

The mechanism for removing nitrogen in water is determined by several factors, including bacterial activity (Gersberg et al. 1986), uptake by plants (Breen 1990), and evaporation (Sanchez-Monedero et al. 2001). In Cyanobacteria, nitrogen is a macronutrient that plays an important role in the formation of biochemical compounds such as nucleic acids (DNA, RNA), amino acids (protein), and pigments (chlorophyll and phycocyanin) (Markou et al. 2014). The results of the LSD 0.05 on the main $\mathrm{pH}$ factor showed that the reduction in total nitrogen content in Arthrospira culture media in treatment P2 was significantly higher than in treatments P1 and P3. This is due to the higher density of Arthrospira in treatment P2 compared to other treatments, so that the utilization of nitrogen by Arthrospira in culture media is greater than in others. Markou et al. (2014) showed that the higher density of Arthrospira could be higher the absorption of nutrients including nitrogen.

The value of reducing total nitrogen content in S3 treatment was significantly higher than for other treatments. This showed that treatment S3 caused Arthrospira to absorb nitrogen higher than other treatments in line with the high density and rendement of phycocyanin Arthrospira obtained in this study. Jabeen and Ahmad (2011) showed that salinity in culture media influences nitrogen absorption and protein biosynthesis. Reduction of total nitrogen content in Arthrospira culture media due to interactions between $\mathrm{pH}$ and salinity factors showed that treatment P2S3 was significantly higher than other treatments. With the optimal conditions ( $\mathrm{pH}$ and salinity), Arthrospira is able to make maximum use of nitrogen. This can be seen from the highest density, growth rate and rendement of phycocyanin found in treatment P2S3. The amount of nitrate and phosphate decreases with increasing growth of Chlorella vulgaris and Arthrospira platensis (Sayadi et al. 2016). This is because algae have the ability to absorb nutrients such as nitrogen and phosphate are use to carry out photosynthesis and protein production.
Reduction of phosphorus content in waters is influenced by the process of absorption, complexation, deposition and assimilation (between microbes and plant biomass) (Tanner et al. 1999).

The results of $\mathrm{LSD}_{0.05}$ on the main factor of $\mathrm{pH}$ showed that each treatment did not significantly affect the reduction of phosphate content in Arthrospira culture medium. Plants can only absorb phosphorus in the form of $\mathrm{H}_{2} \mathrm{PO}_{4}$ and $\mathrm{HPO}_{4}{ }^{-2}$ free orthophosphate ions (Becquer et al. 2014). The orthophosphate content decreases with increasing media pH. Cerozi and Fitzsimmons (2016) showed the orthophosphate content increases in the $\mathrm{pH}$ range from 5.5 to 8.5 and decreases when $\mathrm{pH} 10$. The fall in the orthophosphate content at $\mathrm{pH} 10$ is due to an increase in calcium phosphate formation. The value of reducing the phosphate content in Arthrospira culture medium was presented in Table 5 .

The salinity factor, administration of different salinity in each treatment has no significant effect on reducing the phosphate content. Bassin et al. (2011) explained the reduction of phosphorus will be inhibited when a combination of $\mathrm{Cl}^{-}$and nitrite and $\mathrm{Cl}^{-}$concentration more than $2.5 \mathrm{~g} \mathrm{~L}^{-1}$. The interaction effect of differences in $\mathrm{pH}$ and salinity, each treatment had no significant effect on reducing phosphate content. Hong et al. (1995) showed that the utilization of Dissolved Organic Phosphorus (DOP) can be through active uptake into cells or by extracellular mineralization by phosphatase enzymes. However, most DOP compounds cannot be assimilated directly with microalgae because they have been mineralized. Markou et al. (2014) stated that phosphorus is a macronutrient that plays an important role in the preparation of nucleic acids (RNA and DNA), phospholipids and energy-carrying molecules (ATP). The phosphorus content in plants is lower than Ca, N, and K (Sasaqi et al. 2018). Although the analysis of variance shows that the results are not significantly different, but the highest phosphate reduction still existed in treatment P2S3. 
Table 5. Reduction of phosphate content in Arthrospira culture medium (\%)

\begin{tabular}{cccccc}
\hline \multirow{2}{*}{ Single influence of pH (P) } & \multicolumn{4}{c}{ Single influence of salinity $(\mathbf{S})$} & \multirow{2}{*}{ Main influence of pH (P) } \\
\cline { 2 - 5 } & $\mathbf{S 1}$ & $\mathbf{S 2}$ & $\mathbf{S 3}$ & $\mathbf{S 4}$ & 71.875 \\
P1 & 70.500 & 71.667 & 73.000 & 72.333 & 74.000 \\
P2 & 74.667 & 74.000 & 74.667 & 72.667 & 71.750 \\
P3 & 70.333 & 70.333 & 73.667 & 72.667 & \\
Main influence of salinity (S) & 71.833 & 72.000 & 73.778 & 72.556 & \\
\hline
\end{tabular}

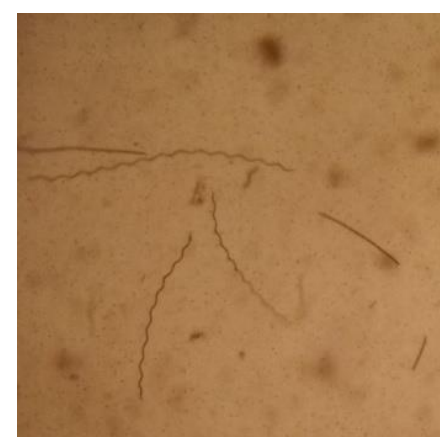

P1S1

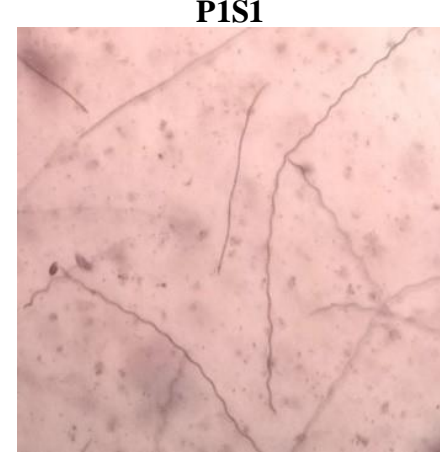

P2S1

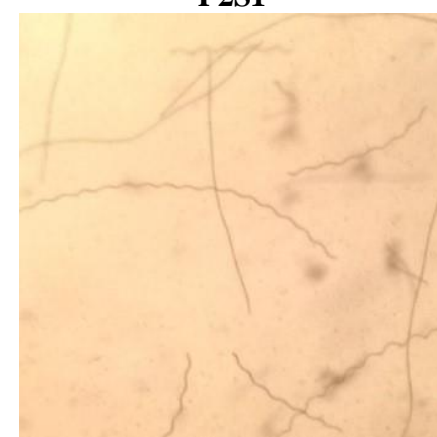

P3S1

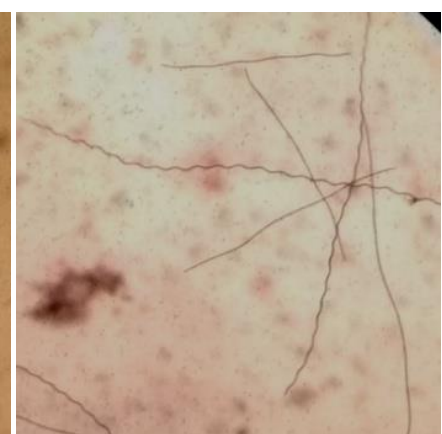

P1S2

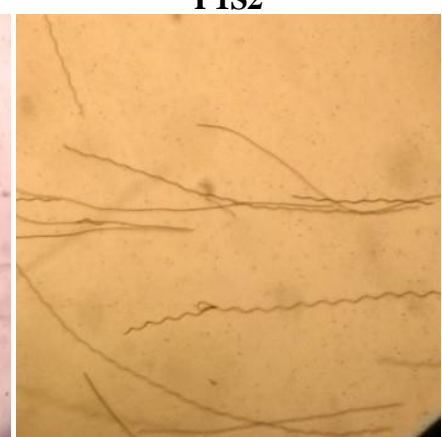

P2S2

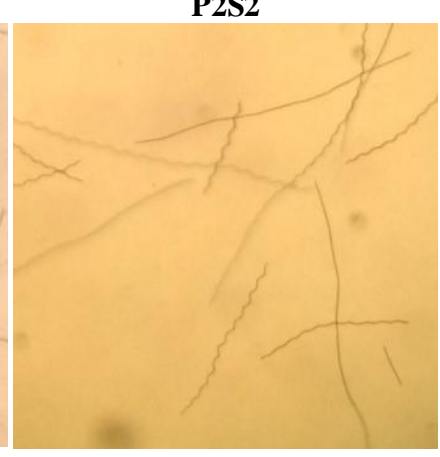

P3S2

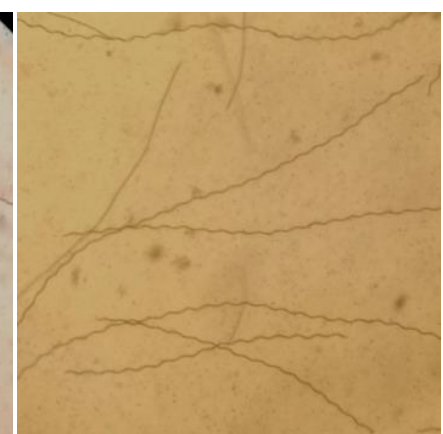

P1S3

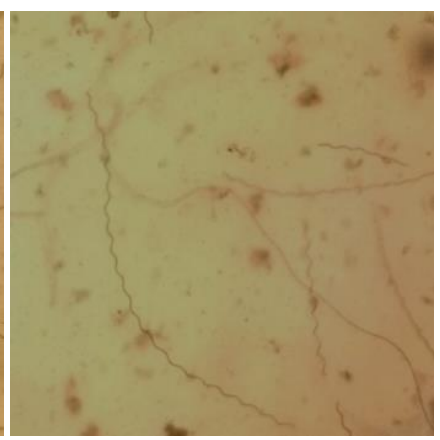

P1S4

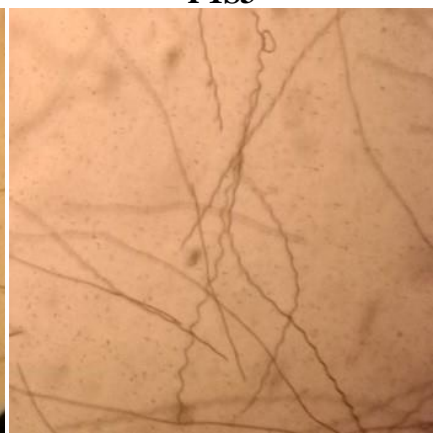

P2S3

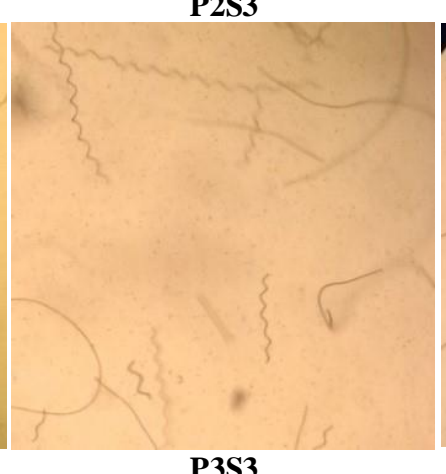

P3S3

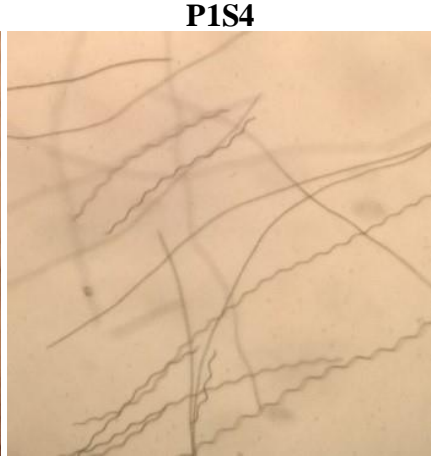

P2S4

Figure 6. Morphology of Arthrospira in catfish wastewater culture media at several treatments of pH and salinity

\section{Morphology of Arthrospira in various pH and salinity media}

Morphology of Arthrospira was affected by increasing or decreasing physical or chemical factors in their culture media. Salinity and acidity value combination at this study didn't change the filament of Arthrospira significantly as their filament of Arthrospira under microscope with 100x magnification (Figure 6). The morphological forms of Arthrospira were not different in all $\mathrm{pH}$ and salinity treatments. The wastewater catfish pond media could be affected in the linearizing filament. This study indicated that salinity and acidity of culture media didn't effect various forms of filament, either straight and helical.

The straight filaments were observed for Arthrospira strains during two years of cultivation, and their presence in Arthrospira sp. Nigrita C1 cultures was constant. The various morphological plasticity, greatly influenced by the growth stage and exogenous parameters, such as temperature and light intensity, was observed for Arthrospira strains (Papapanagiotou and Gkelis 2019). There are indications that adaptability to change in environmental conditions is relatively rapid and also 
subsequent changes at the genetic level can be realized quickly. This means that we can easily find different genotypes in various stable, ecologically different habitats. Morphologically similar strains were cultured for a long time under uniform and stable conditions (Komarek 2016). But the morphological changes could not be effected by acidity and salinity of culture media.

In conclusion, Arthrospira that is cultured on waste media (observed in liquid culture) indicated some short and linear filaments. Identified Arthrospira had a genetic distance of $6.8 \%$ between AF and AW isolates. AF isolates had a close relationship with Arthrospira platensis petH species originating from Japan (bootstrap value of 95\%) while AW isolates form phylogenetic branches which are separated from AF isolates and Arthrospira platensis petH species originating from Japan (bootstrap value $85 \%$ ). The catfish culture wastewater media at different $\mathrm{pH}$ and salinity affects the density, growth rate, and rendement of phycocyanin Arthrospira platensis. The highest density, growth rate and rendement of phycocyanin were in P2S3 treatment $(\mathrm{pH} 8.5 \pm 0.2$ and salinity of $20 \%$ ) which produced a maximum density of $0.867 \mathrm{~g} \mathrm{~L}^{-1}$, growth rate of $22.026 \%$ day $^{-1}$ and the rendement of phycocyanin of $11.334 \%$.

\section{ACKNOWLEDGEMENTS}

We thank staff at Aquaculture Laboratory and Plant Physiology Laboratory, Faculty of Agriculture, Sriwijaya University, Indonesia. The authors also acknowledge the contribution of the Sriwijaya University for Profession Research Grant (No. 0144.25/UN9/SB3.LP2M.PT/2019).

\section{REFERENCES}

Adamowicz SJ. 2015. International Barcode of Life: Evolution of a global research community. Genome 58: 151-162.

Astiani F, Dewiyanti I, Mellisa S. 2016. Pengaruh kultur yang berbeda terhadap laju pertumbuhan dan biomassa Spirulina sp. Jurnal Ilmiah Mahasiswa Kelautan dan Perikanan Unsyiah 1: 441-447. [Indonesian]

Ballot A. Dadheech PK. Krienitz L. 2004. Phylogenetic relationship of Arthrospira, Phormidium and Spirulina strain from Kenyan and Indian waterbodies. Algol Stud 113: 37-56.

Bassin JP, Pronk M, Muyzer G, Kleerebezem R, Dezotti M, Vanloosdrecht MCM. 2011. Effect of elevated salt concentration on the aerobic granular sludge process: Linking microbial activity with microbial community structure. Appl Environ Microbiol 7 (22): 7942 7953.

Becquer A, Trap J, Irshad U, Ali MA, Claude P. 2014. From soil to plant, the journey of $\mathrm{P}$ through trophic relationships and ectomycorrhizal association. Front Plant Sci 5: 1-7.

Bennett A, Bogorad L. 1973. Complementary chromatic adaptation in a filamentous blue-green alga. J Cell Biol 58: 419-435.

Borowitzka MA, Beardal J, Raven JA. 2016. The Physiology of Microalgae. Springer International Publishing, Switzerland.

Boyd CE. 1990. Water Quality in Ponds for Aquaculture. Birmingham Publishing Co., Birmingham, AL.

Breen P. 1990. A mass balance method for assessing the potential of artificial wetlands for wastewater treatment. Water Res 24 (6): 689697

Cerozi B, Fitzsimmons KM. 2016. The effect of $\mathrm{pH}$ on phosphorus availability and speciation in an aquaponics nutrient solution. Bioresour Technol 219: 778-781.
Cifferi O. 1983. Spirulina, the edible organism. Amer Soc Microbiol 47 (4): $551-578$.

Davis CC. 1955. The Marine and Freshwater Plankton. Michigan State University Press, Michigan. USA.

Gersberg RM, Elkins BV, Lyon SR, Goldman CR. 1986. Role of aquatic plants in wastewater treatment by artificial wetlands. Wat Res 20 (3): $363-368$

Guiry MD, Guiry GM. 2010. AlgaeBase. World-wide electronic publication, National University of Ireland, Galway. http: //www.algaebase.org; [14 February 2020].

Hall BG. 2001. Phylogenetic Trees Made Easy: A How-To Manual for Molecular Biologists. Sinauer Associates, Inc. Sunderland, MS.

Hariyati R. 2008. Pertumbuhan dan biomassa Spirulina sp. dalam skala laboratoris. Bioma 10 (1): 19-22. [Indonesian]

Hidayani A, Wijayanti M, Yulisman Y. 2019. Pengaruh pH dan Salinitas Yang Berbeda Pada Air Limbah Budidaya Ikan Lele Terhadap Pertumbuhan dan Rendemen Fikosianin Spirulina platensis. [Hon. Thesis], Budidaya Perairan, Fakultas Pertanian, Universitas Sriwijaya, Ogan Ilir. [Indonesian]

Hillis DM, Bull JJ. 1993. An empirical test of bootstrapping as a method for assessing confidence in phylogenetic analyses. Syst Biol 42: 182192.

Hsieh-Lo M, Castillo G, Ochoa-Becerra MA, Mojica L. 2019. Phycocyanin and phycoerythrin: Strategies to improve production yield and chemical stability. Algal Res 42: 101600. DOI: 10.1016/j.jbiotec.2018.07.025.

Hu Q. 2004. Environmental Effects on Cell Composition. In: Richmond A (ed.). Handbook of Microalgal Culture: Biotechnology and Applied Phycology. Blackwell Science Ltd., Australia.

Hong HS, Wang HL, Huang BQ. 1995. The availability of dissolved organic phosphorus compounds to marine phytoplankton. Chin J Oceanol Limnol 13 (2): 169-176.

Ismaiel MMS, El-Ayouty YM, Piercey-Normore M. 2016. Role of pH on antioxidants production by Spirulina (Arthrospira) platensis. Brazilian J Microbiol 47 (2): 298-304.

Issa AA., Abd-Alla MH, Ohyama T. 2014. Nitrogen-fixing Cyanobacteria: future prospect. In: Ohyama $\mathrm{T}$ (ed.) Advances in Biology and Ecology of Nitrogen Fixation. InTech, Rijeka, Croat.

Jabeen N Ahmad R. 2011. Foliar application of potassium nitrate affects the growth and nitrate reductase activity in sunflower and safflower leaves under salinity. Notulae Botanicae Horti Agrobotanici ClujNapoca 39: 172-178.

Komárek J. 2016. A polyphasic approach for the taxonomy of cyanobacteria: principles and applications, Eur J Phycol 51 (3): 346353, DOI: 10.1080/09670262.2016.1163738.

Komárek J. 2018. Several problems of the polyphasic approach in the modern cyanobacterial system. Hydrobiologia 811: 7-17.

Kouhgardi E, Moazami E, Vaghei RG, Maghsoudloo. 2015. The effect of different salinities on density of Spirulina platensis under laboratory conditions. Bull Environ Pharmacol Life Sci 4 (3): 92-96.

Lee TMH, Carles MC, Hsing IM. 2003. Microfabricated PCRelectrochemical device for simultaneous DNA amplification and detection. Lab on a Chip 3 (2): 100-105.

Lesmana PA, Diniarti N, Setyono BDH. 2019. Pengaruh penggunaan limbah air budidaya ikan lele sebagai media pertumbuhan Spirulina platensis. Jurnal perikanan 9 (1): 50-65. [Indonesian]

Liu $H$, Zhang $H$, Niedzwiedzki DM, Prado M, He G, Gross ML Blankenship RE. 2013. Phycobilisomes supply excitations to both photosystems in a megacomplex in cyanobacteria. Science 342: 11041107.

Liu J, Yan HF, Ge XJ. 2016. The use of DNA Barcoding on recently diverged species in the Genus Gentiana (Gentianaceae) in China. PLoS ONE 11(4): e0153008. DOI: 10.1371/journal.pone.0153008.

Marek RW, Bazin MJ, Hohn P. 1987. Computer control of carbonnitrogen ratio in Spirulina platensis. Biotechnol Bioeng 29: 520-528.

Markou G, Vandamme D, Muylaert K. 2014. Microalgal and cyanobacteria cultivation: The supply of nutrients. Water Res 65: 186-202.

Nogueira SMS, Junior JS, Maia HD, Saboya JPS, Farias WRL. 2018. Use of Spirulina platensis in treatment of fish farming wastewater. Sci Art 49 (4): 599-606.

Papapanagiotou G, Gkelis S. 2019. Taxonomic revision of commercially used Arthrospira (Cyanobacteria) strains: a polyphasic approach, Eur J Phycol 54 (4): 595-608. DOI: 10.1080/09670262.2019.1624832 
Pirenantyo P, Limantara L. 2008. Pigmen Spirulina sebagai senyawa antikanker. Indon J Cancer 4: 155-163. [Indonesian]

Pisal DS, Lele SS. 2005. Carotenoid from microalga, Dunaliella salina. Indian J Biotechnol 4: 476-483.

Planes P, Rouanet JM, Laurent C, Baccou JC, Besançon P, Caporiccio B 2002. Magnesium bioavailability from magnesium-fortified Spirulina in cultured human intestinal Caco-2 cells. Food Chem 77 (2): 213 218.

Prasadi O. 2018. Pertumbuhan dan biomassa Spirulina sp. dalam media pupuk sebagai bahan fungsional. JIPK 10 (2): 199-123. [Indonesian]

Rahmawati SI, Hidayatulloh S, Suprayatmi M. 2017. Ekstraksi fikosianin dari Spirulina platensis sebagai biopigmen dan antioksidan. Jurnal Pertanian 8 (1): 36-45. [Indonesian]

Ragaza JA, Hossain MS, Meiler KA, Velasquez SF, Kumar V. 2020. A review on Spirulina: alternative media for cultivation and nutritive value as an aquafeed. Rev Aquacult. DOI: 10.1111/raq.12439.

Ravelonandro PH, Ratianarivo DH, Joannis-Cassan C, Isambert A, Raherimandimby. 2011. Improvement of the growth of Arthrospira (Spirulina) platensis from Toliara (Madagascar): Effect of agitation, salinity and $\mathrm{CO}_{2}$ addition. Food Product Proc 8 (9): 209-216.

Sanchez-Monedero MA, Roig A, Paredes C, Bernal MP. 2001. Nitrogen transformation during organic waste composting by the Rutgers system and its effect on $\mathrm{pH}, \mathrm{EC}$ and maturity of the composting mixtures. Bioresour Technol 78: 301-308.

Sasaqi D, Yahdi, Krismayanti L. 2018. Pengaruh tingkat pH, fosfat, nitrat dan ammonium terhadap pertumbuhan eceng gondok di perairan bendungan Batuhai, Kabupaten Lombok Tengah. Jurnal Tadris IPA 3 (1): 156-175 [Indonesian].

Sayadi MH, Ahmadpour N, Capoorchali MF, Rezaei MR. 2016. Removal of nitrate and phosphate from aqueous solution by microalgae: An experimental study. Global J Environ Sci Manag 2 (3): 357-364.

Sharma NK, Tiwari SP. 2011. Sustainability and cyanobacteria (bluegreen algae): facts and challenges. Jurnal Appl Phycol, 23: 10591081.

Simeunovic J, Beslin K, Svireev Z, Lovac D, Babic O. 2013. Impact of nitrogen and drought on phycobiliprotein content in terrestrial strain. J Appl Phycol 25: 597-607.

Soni RA, Sudhakar K, Rana RS. 2019. Comparative study on the growth performance of Spirulina platensis on modifying culture media. Energy Rep 5: 327-226.

Tang DYY, Khoo KS, Chew KW, Tao Y, Ho SH, Show PL. 2020 Potential utilization of bioproducts from microalgae for the quality enhancement of natural products. Bioresour Technol 304: 122997.

Tiwari AK, Tiwari BS. 2020. Cyanotherapeutics: an emerging field for future drug discovery. Appl Phycol 1 (1): 1-14.
Tanner CC, Sukias JPS, Upsdell MP. 1999. Substratum phosphorus accumulation during maturation of gravel-bed constructed wetlands. Wetlands Sci Technol 40 (3): 147-154.

Taufiqurrahmi N, Religia P, Mulyani G, Suryana D, Ichsan, Tanjung FA, Arifin Y. 2017. Phycocyanin extraction in Spirulina produced using agricultural waste. IOP Conf Ser Material Sci Eng 206L: 012097. DOI: $10.1088 / 1757-899 X / 206 / 1 / 012097$

Thajuddin N, Subramanian G. 2005. Cyanobacterial biodiversity and potential applications in biotechnology. Curr Sci 89 (1): 47-57.

Ughy B, Nagy CI, Kos PB. 2015. Biomedical potential of cyanobacteria and algae. Acta Biologica Szegediensis 59 (2): 203-224.

Vernes L, Granvillain P, Chemat F, Vian M. 2015. Phycocyanin from Arthrospira platensis: Production, extraction and analysis. Curr Biotechnol 4 (4): 481-491

Vonshak A. 1997. Spirulina: Growth, physiology and biochemistry. In: Vonshak A (ed.) Spirulina platensis (Arthrospira) Physiology, CellBiology and Biotechnology. Ben-Gurion University of the Negev, Negev.

Vonshak A, Tomaselli L. 2000. Arthrospira (Spirulina): systematics and ecophysiology. In: Whitton BA, Potts M. (eds.), Ecology of Cyanobacteria. Kluwer Academic Publishing, Netherlands.

Wang ZP, Zhao Y. 2005. Morphological reversion of Spirulina (Arthrospira) platensis (Cyanophyta): from linear to helical. J Phycol 41: 622-628

Widyantoro H, Wijayanti M, Dwinanti SH. 2018. Modifikasi media Spirulina platensis sebagai upaya pemanfaatan air limbah budidaya ikan lele. Jurnal Akuakultur Rawa Indonesia 6: 153-164 [Indonesian]

Wijayanti M, Jubaedah D, Gofar N, Anjastari D. 2018. Optimization of Spirulina platensis Culture Media as an Effort for Utilization of Pangasius Farming Waste Water. Sriwijaya J Environ 3 (3): 108-112.

Yadav A, Monsieurs P, Misztak A, Waleron K, Leys N, Cuypers A, Janssen PJ. 2020. Helical and linear morphotypes of Arthrospira sp. PCC 8005 display genomic differences and respond differently to ${ }^{60} \mathrm{Co}$ gamma irradiation, Eur J Phycol 55 (2): 129-146.

Zhang F, Man YB, Mo WY, Wong MH. 2019. Application of Spirulina in aquaculture: a review on wastewater treatment and fish growth. Rev Aquacult 12 (2): 582-599.

Zhao F, Zhang X, Liang C, Wu J, Bao Q, Qin S. 2006. Genome-wide of restriction-modification system in unicellular and filamentous cyanobacteria. Physiol Genomic 24: 181-190

Zhou W, Li Y, Gao Y, Zhao H. 2017. Nutrients removal and recovery from saline wastewater by Spirulina platensis. Bioresour Technol 245: 10-17. 